OPEN ACCESS

Edited by:

Fen Wang,

Texas A\&M University, United States

Reviewed by:

Weijia Luo,

Texas A\&M Health Science Center,

United States

Jue Zhang,

Morgridge Institute for Research,

United States

*Correspondence:

Chenying $\mathrm{Fu}$

fcying_2004@163.com

Quan Wei

weiquan@scu.edu.cn

Specialty section:

This article was submitted to

Signaling,

a section of the journa

Frontiers in Cell and Developmental

Biology

Received: 21 October 2021 Accepted: 11 November 2021 Published: 02 December 2021

Citation:

Wang Y, Tan J, Wang L, Pei G, Cheng $H$, Zhang $Q$, Wang S, He C, Fu C and Wei Q (2021) MiR-125 Family in Cardiovascular and

Cerebrovascular Diseases. Front. Cell Dev. Biol. 9:799049. doi: 10.3389/fcell.2021.799049

\section{MiR-125 Family in Cardiovascular and Cerebrovascular Diseases}

\author{
Yang Wang ${ }^{1,2}$, Jing Tan $^{3}$, Lu Wang ${ }^{1,2}$, Gaiqin Pei ${ }^{1,2}$, Hongxin Cheng ${ }^{1,2}$, Qing Zhang ${ }^{1,2}$, \\ Shiqi Wang ${ }^{1,2}$, Chengqi He ${ }^{1,2}$, Chenying $\mathrm{Fu}^{4,5 *}$ and Quan Wei ${ }^{1,2 \star}$ \\ ${ }^{1}$ Department of Rehabilitation Medicine Center, West China Hospital, Sichuan University, Chengdu, China, ${ }^{2}$ Key Laboratory of \\ Rehabilitation Medicine in Sichuan Province, Chengdu, China, ${ }^{3}$ Department of Ultrasound Medicine, Binzhou People's Hospital, \\ Binzhou, China, ${ }^{4}$ National Clinical Research Center for Geriatrics, West China Hospital, Sichuan University, Chengdu, China, \\ ${ }^{5}$ Aging and Geriatric Mechanism Laboratory, West China Hospital, Sichuan University, Chengdu, China
}

Cardiovascular and cerebrovascular diseases are a serious threaten to the health of modern people. Understanding the mechanism of occurrence and development of cardiovascular and cerebrovascular diseases, as well as reasonable prevention and treatment of them, is a huge challenge that we are currently facing. The miR-125 family consists of hsa-miR-125a, hsa-miR-125b-1 and hsa-miR-125b-2. It is a kind of miRNA family that is highly conserved among different species. A large amount of literature shows that the lack of miR-125 can cause abnormal development of the cardiovascular system in the embryonic period. At the same time, the miR-125 family participates in the occurrence and development of a variety of cardiovascular and cerebrovascular diseases, including myocardial ischemia, atherosclerosis, ischemia-reperfusion injury, ischemic stroke, and heart failure directly or indirectly. In this article, we summarized the role of the miR-125 family in the development and maturation of cardiovascular system, the occurrence and development of cardiovascular and cerebrovascular diseases, and its important value in the current fiery stem cell therapy. In addition, we presented this in the form of table and diagrams. We also discussed the difficulties and challenges faced by the miR-125 family in clinical applications.

\section{Keywords: cardiovascular and cerebrovascular diseases, mir-125, atherosclerosis, myocardial ischemia, ischemia- reperfusion, ischemic stroke, mesenchymal stem cell}

\section{INTRODUCTION}

Cardiovascular disease is one of the leading causes of death in the world. A retrospective study from 204 countries around the world found that from 1990 to 2019, the total number of cardiovascular diseases increased from 271 million to 523 million, and the number of cardiovascular deaths increased from 12.1 million to 18.6 million (Roth et al., 2020). Therefore, we should actively explore the occurrence and development mechanism of cardiovascular disease, which is of great significance to alleviate the pressure of health system and improve the quality of life on a global scale.

Although it has been nearly 30 years since the first microRNA (miRNA) was discovered, the research on miRNA is still hot. Earlier studies found that miRNA expression was tissue-specific, that is, specific miRNAs were expressed only in specific cells or tissues (Lagos-Quintana et al., 2002). It was discovered that most miRNAs could be expressed in different organs or cells, and some of them were highly expressed among different species (Ludwig et al., 2016). Many studies have shown that miRNAs play an important regulatory role in the occurrence and development of diseases, and 
TABLE 1 | Summary of studies investigating the regulators and effectors of miR-125 family in cardiovascular and cerebrovascular diseases.

\begin{tabular}{|c|c|c|c|c|c|c|c|}
\hline Reference & miRNA & $\begin{array}{l}\text { Target cells/ } \\
\text { tissues/organs }\end{array}$ & Disease or phenotype & Intervention & $\begin{array}{l}\text { Experimental } \\
\text { setting }\end{array}$ & Species & $\begin{array}{l}\text { Target } \\
\text { genes }\end{array}$ \\
\hline Li et al. (2018) & miR-125 & $\mathrm{H} 9 \mathrm{c} 2$ & Oxidative stress & $\mathrm{H}_{2} \mathrm{O}_{2}$ & In vitro & Rat & MMP2 \\
\hline $\begin{array}{l}\text { Gródecka-Szwajkiewicz } \\
\text { et al. (2020) }\end{array}$ & $\mathrm{miR}-125$ & Plasma & Premature birth & $\mathrm{N}$ & In vivo & Human & $\mathrm{N}$ \\
\hline Díaz et al. (2017) & $\begin{array}{l}\mathrm{miR}- \\
125 \mathrm{a}\end{array}$ & Myocardial cells & I/R injury & I/R, Urocortin & In vitro, In vivo & Rat & $\begin{array}{l}\text { BRCA1, } \\
\text { MAP3K12, } \\
\text { XBP1, TAZ, } \\
\text { CPT2, } \\
\text { MTFR1 }\end{array}$ \\
\hline Svensson et al. (2014) & $\begin{array}{l}\mathrm{miR}- \\
125 \mathrm{a}\end{array}$ & $\begin{array}{l}\text { HUVECs, Arterial } \\
\text { endothelial cells }\end{array}$ & $\begin{array}{l}\text { Endothelial cell } \\
\text { proliferation and viability }\end{array}$ & Growth factors & In vitro & Human & $\begin{array}{l}\text { Bcl2, } \\
\text { caspase-3 }\end{array}$ \\
\hline Maitrias et al. (2015) & $\begin{array}{l}\mathrm{miR}- \\
125 \mathrm{a}\end{array}$ & Carotid plaque & Carotid plaque & $\mathrm{N}$ & In vivo & Human & $\mathrm{N}$ \\
\hline Zhang and Niu, (2020) & $\begin{array}{l}\mathrm{miR}- \\
125 \mathrm{a}\end{array}$ & Plasma & Acute ischemic stroke & $\mathrm{N}$ & In vivo & Human & $\mathrm{N}$ \\
\hline Chen et al. (2018) & $\begin{array}{l}\mathrm{miR}- \\
125 \mathrm{a}\end{array}$ & HUVECs & Oxidative stress & $\mathrm{H}_{2} \mathrm{O}_{2}$ & In vitro & Human & $\operatorname{TrxR1}$ \\
\hline Ye et al. (2020) & $\begin{array}{l}\mathrm{miR}- \\
125 \mathrm{a}\end{array}$ & VSMCs & $\begin{array}{l}\text { AS, VSMCs proliferation } \\
\text { and migration }\end{array}$ & High glucose & In vitro & Rat & HMGCR \\
\hline Li et al. (2020) & $\begin{array}{l}\mathrm{miR}- \\
125 \mathrm{a}\end{array}$ & Plasma & Acute ischemic stroke & $\mathrm{N}$ & In vivo & Human & $\mathrm{N}$ \\
\hline Hu et al. (2019) & $\begin{array}{l}\text { miR- } \\
125 a-3 p\end{array}$ & VSMCs & $\begin{array}{l}\text { VSMCs proliferation and } \\
\text { migration }\end{array}$ & $\begin{array}{l}\text { Carotid artery balloon } \\
\text { injury, Platelet derived } \\
\text { growth factor }\end{array}$ & In vitro, In vivo & Rat & MAPK1 \\
\hline Wang et al. (2019b) & $\begin{array}{l}\text { miR- } \\
125 a-5 p\end{array}$ & VSMCs & AS & $\begin{array}{l}\text { Oxidized low-density } \\
\text { lipoprotein }\end{array}$ & In vitro & Human & CCL4 \\
\hline Zhou et al. (2021) & $\begin{array}{l}\text { miR- } \\
125 a-5 p\end{array}$ & VSMCs & $\begin{array}{l}\text { VSMCs proliferation, } \\
\text { migration and invasion }\end{array}$ & High glucose & In vitro & Rat & EGFR \\
\hline $\begin{array}{l}\text { Hendgen-Cotta et al. } \\
\text { (2017) }\end{array}$ & $\begin{array}{l}\text { miR- } \\
125 a-5 p\end{array}$ & Heart & I/R injury & I/R,Nitrite & In vivo & Mouse & $\mathrm{N}$ \\
\hline Che et al. (2014) & $\begin{array}{l}\text { miR- } \\
125 a-5 p\end{array}$ & $\begin{array}{l}\text { Arterial endothelial } \\
\text { cell }\end{array}$ & Aging & $\mathrm{N}$ & In vitro & Mouse & RTEF-1 \\
\hline Galluzzo et al. (2021) & $\begin{array}{l}\text { miR- } \\
125 a-5 p\end{array}$ & Serum & Advanced heart failure & $\mathrm{N}$ & In vivo & Human & $\mathrm{N}$ \\
\hline Gareri et al. (2017) & $\begin{array}{l}\text { miR- } \\
125 a-5 p\end{array}$ & VSMCs, A10 & $\begin{array}{l}\text { Carotid artery balloon } \\
\text { injury }\end{array}$ & $\begin{array}{l}\text { Carotid artery balloon } \\
\text { injury }\end{array}$ & In vitro, In vivo & Rat & ETS-1 \\
\hline Zheng et al. (2019) & $\begin{array}{l}\text { miR- } \\
125 a-5 p\end{array}$ & VSMCs & VSMCs proliferation & $\begin{array}{l}\text { Platelet derived growth } \\
\text { factor-BB, Vein graft }\end{array}$ & In vitro, In vivo & Rat & IRF1 \\
\hline Zhaolin et al. (2019) & $\begin{array}{l}\text { miR- } \\
125 a-5 p\end{array}$ & HUVECS & AS & $\begin{array}{l}\text { Oxidized low-density } \\
\text { lipoprotein }\end{array}$ & In vitro & Human & TET2 \\
\hline $\begin{array}{l}\text { Kijpaisalratana et al. } \\
(2020)\end{array}$ & $\begin{array}{l}\text { miR- } \\
125 a- \\
5 p, \text { miR- } \\
125 b-5 p\end{array}$ & Serum & $\begin{array}{l}\text { Posterior circulation } \\
\text { stroke/Peripheral vertigo }\end{array}$ & $\mathrm{N}$ & In vivo & Human & $\mathrm{N}$ \\
\hline Tiedt et al. (2017) & $\begin{array}{l}\text { miR- } \\
125 a- \\
5 p, \text { miR- } \\
125 b-5 p\end{array}$ & Plasma & Acute ischemic stroke & $\mathrm{N}$ & In vivo & Human & $\mathrm{N}$ \\
\hline Li et al. (2010) & $\begin{array}{l}\text { miR- } \\
125 a- \\
5 p, \text { miR- } \\
125 b-5 p\end{array}$ & $\begin{array}{l}\text { H5V, b.END.3, } \\
\text { VSMCs, NIH3T3 }\end{array}$ & Oxidative stress & $\begin{array}{l}\text { Oxidized low-density } \\
\text { lipoprotein }\end{array}$ & In vitro, In vivo & $\begin{array}{l}\text { Stroke-prone } \\
\text { spontaneously } \\
\text { hypertensive rats }\end{array}$ & PreproET-1 \\
\hline Ke et al. (2019) & $\begin{array}{l}\text { miR- } \\
125 a- \\
5 p, \text { miR- } \\
125 b-5 p\end{array}$ & $\begin{array}{l}\text { Hippocampal } \\
\text { tissues }\end{array}$ & I/R injury & l/R & $\begin{array}{l}\text { Bioinformatics } \\
\text { analysis }\end{array}$ & Rat & $\mathrm{N}$ \\
\hline Wang et al. (2021) & $\begin{array}{l}\mathrm{miR}- \\
125 \mathrm{~b}\end{array}$ & VSMCs & $\begin{array}{l}\text { Vascular smooth muscle } \\
\text { cells proliferation }\end{array}$ & $\mathrm{N}$ & In vitro & Rat & AAMP, SRF \\
\hline Nagpal et al. (2016) & $\begin{array}{l}\mathrm{miR}- \\
125 \mathrm{~b}\end{array}$ & Cardiac fibroblasts & Myocardial fibrosis & Angiotensin II, TGF- $\beta 2$ & In vitro, In vivo & Human, Mouse & Apelin, P53 \\
\hline Xu and Fang, (2021) & $\begin{array}{l}\mathrm{miR}- \\
125 \mathrm{~b}\end{array}$ & Myocardial cells & $\begin{array}{l}\text { Diabetic } \\
\text { cardiomyopathy/ } \\
\text { Myocardial cell death }\end{array}$ & High glucose & In vitro, In vivo & Human, Rat & HK2, LDHA \\
\hline
\end{tabular}


TABLE 1 | (Continued) Summary of studies investigating the regulators and effectors of miR-125 family in cardiovascular and cerebrovascular diseases.

\begin{tabular}{|c|c|c|c|c|c|c|c|}
\hline Reference & miRNA & $\begin{array}{l}\text { Target cells/ } \\
\text { tissues/organs }\end{array}$ & Disease or phenotype & Intervention & $\begin{array}{l}\text { Experimental } \\
\text { setting }\end{array}$ & Species & $\begin{array}{l}\text { Target } \\
\text { genes }\end{array}$ \\
\hline Zhang et al. (2021) & $\begin{array}{l}\mathrm{miR}- \\
125 b\end{array}$ & Myocardial cells & $\begin{array}{l}\text { Heart failure/ } \\
\text { Cardiomyocyte } \\
\text { apoptosis }\end{array}$ & $\begin{array}{l}\text { Transverse aortic } \\
\text { constriction }\end{array}$ & In vitro, In vivo & Mouse & Bak1 \\
\hline Liang et al. (2018) & $\begin{array}{l}\mathrm{miR}- \\
125 b\end{array}$ & PC12 & I/R injury & I/R,OGD & In vitro & Rat & $\mathrm{CK} 2 a$ \\
\hline Cheng et al. (2015) & $\begin{array}{l}\mathrm{miR}- \\
125 b\end{array}$ & Immune cells & Aging & $N$ & In vivo & Human & CCL4 \\
\hline Sun et al. (2020) & $\begin{array}{l}\text { miR- } \\
125 b\end{array}$ & Cardiac fibroblasts & AMl & $\begin{array}{l}\text { Circ-LAS1L } \\
\text { overexpression vector }\end{array}$ & In vitro & Human & SFRP5 \\
\hline Bie et al. (2016) & $\begin{array}{l}\mathrm{miR}- \\
125 b\end{array}$ & Cardiac fibroblasts & $\begin{array}{l}\text { Cardiac fibroblasts } \\
\text { growth and activation }\end{array}$ & $\mathrm{N}$ & In vitro & Human & SFRP5 \\
\hline Wang et al. (2014) & $\begin{array}{l}\mathrm{miR}- \\
125 b\end{array}$ & $\mathrm{H} 9 \mathrm{c} 2$ & I/R injury & $\mathrm{l} / \mathrm{R}$ & In vitro, In vivo & $\begin{array}{l}\text { Transgenic mice } \\
\text { with } \\
\text { overexpression of } \\
\text { miR-125b + Rat }\end{array}$ & $\begin{array}{l}\text { P53, Bak1, } \\
\text { TRAF6 }\end{array}$ \\
\hline Wen et al. (2014) & $\begin{array}{l}\text { miR- } \\
125 b\end{array}$ & VSMCs & $\begin{array}{l}\text { VSMCs } \\
\text { transdifferentiation and } \\
\text { calcification }\end{array}$ & $\begin{array}{l}\beta \text {-glycerophosphoric } \\
\text { acid }\end{array}$ & In vitro & Rat & Ets1 \\
\hline Cao et al. (2016) & $\begin{array}{l}\mathrm{miR}- \\
125 b\end{array}$ & VSMCs & AS, VSMCs proliferation & $\begin{array}{l}\text { Homocysteine, } \\
\text { Methionine diet }\end{array}$ & In vitro, In vivo & $\begin{array}{l}\text { Human, ApoE }{ }^{-/-} \\
\text {mouse }\end{array}$ & DNMT3b \\
\hline Xiao et al. (2018) & $\begin{array}{l}\mathrm{miR}- \\
125 b\end{array}$ & $\begin{array}{l}\text { MSCs, } \\
\text { cardiomyocytes }\end{array}$ & Ml, Autophagic Flux & MI, OGD, Co-culture & In vitro, In vivo & Mouse & P53 \\
\hline Wong et al. (2012) & $\begin{array}{l}\text { miR- } \\
125 b\end{array}$ & ESCs & Embryo differentiation & $N$ & In vitro & Human & $\operatorname{Lin} 28$ \\
\hline Fan et al. (2020) & $\begin{array}{l}\mathrm{miR}- \\
125 b\end{array}$ & $\begin{array}{l}\mathrm{H} 9 \mathrm{c} 2 \text {, } \\
\text { Cardiomyocytes }\end{array}$ & Cardiomyocyte injury & Hypoxia & In vitro & Rat & HK2 \\
\hline Ding et al. (2015) & $\begin{array}{l}\text { miR- } \\
125 b\end{array}$ & Plasma & Coronary heart disease & $N$ & In vivo & Human & $N$ \\
\hline Zhu et al. (2018) & $\begin{array}{l}\text { miR- } \\
125 b\end{array}$ & $\begin{array}{l}\text { Bone marrow } \\
\text { mesenchymal } \\
\text { stem cells, H9C2 }\end{array}$ & $\mathrm{Ml}$ & $\begin{array}{l}\text { MI, Hypoxia, Co- } \\
\text { culture, Reactive } \\
\text { dibenzylcyclootyne }\end{array}$ & In vitro, In vivo & Mouse & P53, Bak1 \\
\hline Xiaochuan et al. (2020) & $\begin{array}{l}\mathrm{miR}- \\
125 b\end{array}$ & Myocardial cells & AMl & $\begin{array}{l}\text { AMI, Adenoviruses } \\
\text { containing RASSF1 } \\
\text { siRNA, hypoxia }\end{array}$ & In vivo & Rat & RASSF1 \\
\hline Chen et al. (2021) & $\begin{array}{l}\text { miR- } \\
125 b-1\end{array}$ & Heart & Birth defects & $\begin{array}{l}\text { Cardiac-specific miR- } \\
\text { 125b-1 KO }\end{array}$ & In vivo & $\begin{array}{l}\text { Cardiac specific } \\
\text { miR-125b-1 KO } \\
\text { mouse }\end{array}$ & $\begin{array}{l}\text { BTG2, } \\
\text { Pafah1b1 }\end{array}$ \\
\hline Szabó et al. (2020) & $\begin{array}{l}\text { miR- } \\
125 b- \\
1-3 p\end{array}$ & Heart & $\begin{array}{l}\text { Hypercholesterolemia, I/ } \\
\text { R injury }\end{array}$ & Special Diet, I/R & In vitro, In vivo & Rat & $N$ \\
\hline Deng et al. (2015) & $\begin{array}{l}\text { miR- } \\
125 b-2\end{array}$ & $\begin{array}{l}\text { Embryonic stem } \\
\text { cells, E14TG2A }\end{array}$ & Birth defects & All-trans-retinoic acid & In vitro & Mouse & $N$ \\
\hline Dufeys et al. (2021) & $\begin{array}{l}\text { miR- } \\
125 b-5 p\end{array}$ & Cardiac fibroblasts & Ml/Myocardial fibrosis & $\begin{array}{l}\text { Myofibroblasts -specific } \\
\text { AMPKa1 KO }\end{array}$ & In vitro, In vivo & $\begin{array}{l}\text { Human, AMPKa1 } \\
\text { KO mouse }\end{array}$ & $\mathrm{C} \times 43$ \\
\hline Nazari-Shafti et al. (2020) & $\begin{array}{l}\text { miR- } \\
125 b-5 p\end{array}$ & $\begin{array}{l}\text { MSCs extracellular } \\
\text { vehicles }\end{array}$ & $N$ & $\mathrm{~N}$ & In vitro & Human & $\mathrm{N}$ \\
\hline Ben-Zvi et al. (2020) & $\begin{array}{l}\text { miR- } \\
125 b-5 p\end{array}$ & Serum & Systolic heart failure & $\mathrm{N}$ & In vivo & Human & $\mathrm{N}$ \\
\hline Lee et al. (2015) & $\begin{array}{l}\text { miR- } \\
125 b-5 p\end{array}$ & $\begin{array}{l}\text { Embryonic stem } \\
\text { cells, H9 }\end{array}$ & $\begin{array}{l}\text { Embryonic stem cells } \\
\text { maturation }\end{array}$ & Co-culture & In vitro & $\begin{array}{l}\text { Human, } \\
\text { Mouse, Rat }\end{array}$ & ErbB4 \\
\hline Chen et al. (2020) & $\begin{array}{l}\text { miR- } \\
125 b-5 p\end{array}$ & HT-22 & l/R injury & $\begin{array}{l}\text { Oxygen Glucose } \\
\text { Deprivation }\end{array}$ & In vitro & Mouse & GDF11 \\
\hline Bayoumi et al. (2018) & $\begin{array}{l}\text { miR- } \\
125 b-5 p\end{array}$ & $\begin{array}{l}\text { HL-1, H9c2, } \\
\text { Ventricular } \\
\text { cardiomyocytes }\end{array}$ & AMI, l/R injury & AMI, I/R, Carvedilol & In vitro, In vivo & Mouse, Rat & Bak1, Klf13 \\
\hline Jia et al. (2016) & $\begin{array}{l}\text { miR- } \\
125 b-5 p\end{array}$ & Plasma & $\begin{array}{l}\text { Acute myocardial } \\
\text { infarction }\end{array}$ & $N$ & In vivo & Human & $\mathrm{N}$ \\
\hline Lin et al. (2021) & $\begin{array}{l}\text { miR- } \\
125 b-5 p\end{array}$ & $\begin{array}{l}\text { Bone marrow } \\
\text { mesenchymal } \\
\text { stem cells, } \\
\text { VSMCs, Aortic } \\
\text { tissues }\end{array}$ & AS & $\begin{array}{l}\text { High fat diet, Tail vein } \\
\text { injection }\end{array}$ & In vitro, In vivo & Apoe $^{-/-}$mouse & Map4k4 \\
\hline Lu et al. (2016) & $\begin{array}{l}\mathrm{miR}- \\
125 b-5 p\end{array}$ & $\begin{array}{l}\text { THP-1, } \\
\text { Atherosclerotic } \\
\text { plaques }\end{array}$ & AS & LPS & In vitro, In vivo & Human & LACTB \\
\hline
\end{tabular}




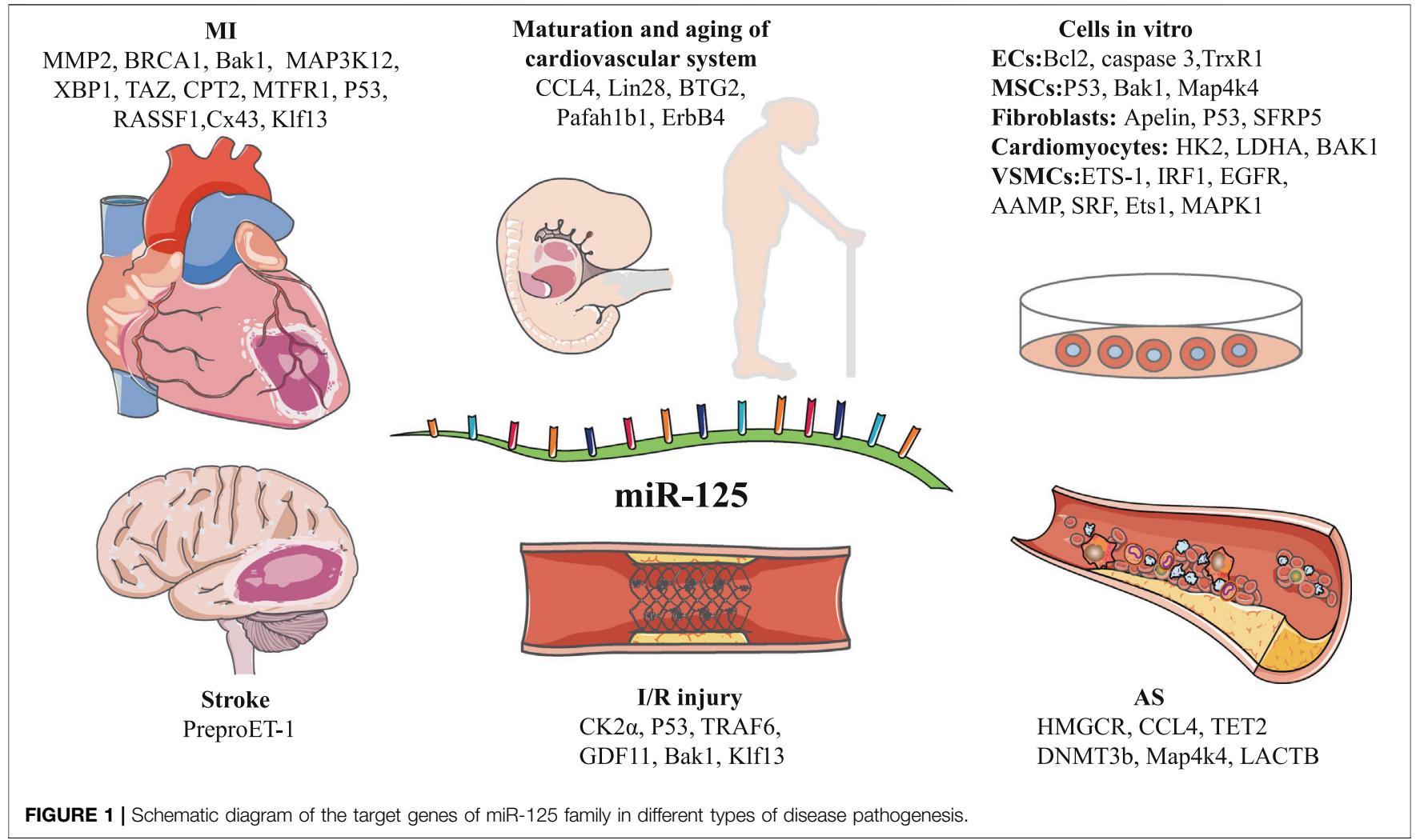

sometimes even in different stages in the same disease. Many miRNAs were highly conserved between different species (Perge et al., 2017). In different species, this provides us with the possibility to study whether the same miRNA plays the same role in the same disease, including cardiovascular and cerebrovascular diseases. For example, in both early and late stages, miR-19a/19b could protect cardiomyocytes in mice after myocardial infarction (MI) (Gao et al., 2019). Therapeutic silencing miR-146b-5p improved cardiac remodeling in porcine and mouse model of MI (Liao et al., 2021). MiR-21 from exosomes in human cardiomyocytes could be used to treat MI injury models in mice (Qiao et al., 2019).

MiR-125 family is widely expressed in mammals and its sequence is highly conserved. It is composed of three homologs hsa-miR-125a, hsa-miR-125b-1 and hsa-miR-125b-2 (Sun et al., 2013). hsa-miR-125a was discovered to be located at 19q13, while hsa-miR-125b-1 was verified on chromosomes $11 \mathrm{q} 23$ and hsa-miR-125b-2 on chromosomes $21 \mathrm{q} 21$ (Rodriguez et al., 2004). The miR-125 family plays an important role in the growth and development of animals, as well as the occurrence and development of cancer (Kim et al., 2016; Wang et al., 2019a). In addition, the role of miR-125 in cardiovascular and cerebrovascular diseases cannot be ignored. This article will review the role and mechanism of miR-125 family in the occurrence and development of cardiovascular and cerebrovascular diseases, including the role of the miR-125 family in the development and maturation of cardiovascular system, the occurrence and development of cardiovascular and cerebrovascular diseases, and its value in the stem cell therapy. Furthermore, we presented this in the form of tables and diagrams (Table1; Figures 1, 2). Finally, we also discussed the challenges faced by the miR-125 family in clinical applications in the future.

\section{MIR-125 FAMILY AND THE MATURATION AND AGING OF CARDIOVASCULAR SYSTEM}

It was reported that when miR-125b-1 was specifically knocked out in the mouse heart, the mortality rate of perinatal mice was as high as $60 \%$. Even in the surviving mice, their hearts were hypertrophy to varying degrees, and the mitochondria of the cardiomyocytes of these mice experienced varying degrees of morphological changes and loss of function in terms of morphology and function (Chen et al., 2021). Coincidentally, overexpression of miR-125b-2 in mouse embryonic stem cells (ESCs) inhibited the differentiation of mouse ESCs into endoderm and ectoderm, but it did not affect mesoderm differentiation, self-renewal and proliferation of mouse ESCs (Deng et al., 2015). Since the mesoderm was the origin of heart development, this study also indirectly showed that miR$125 \mathrm{~b}-2$ may play a role in maintaining the normal development of the heart in early mouse embryos. If murine and human embryonic-stem-cell-derived cardiomyocytes (m/hESC-CMs) were co-cultured with endothelial cells or endothelial cell 


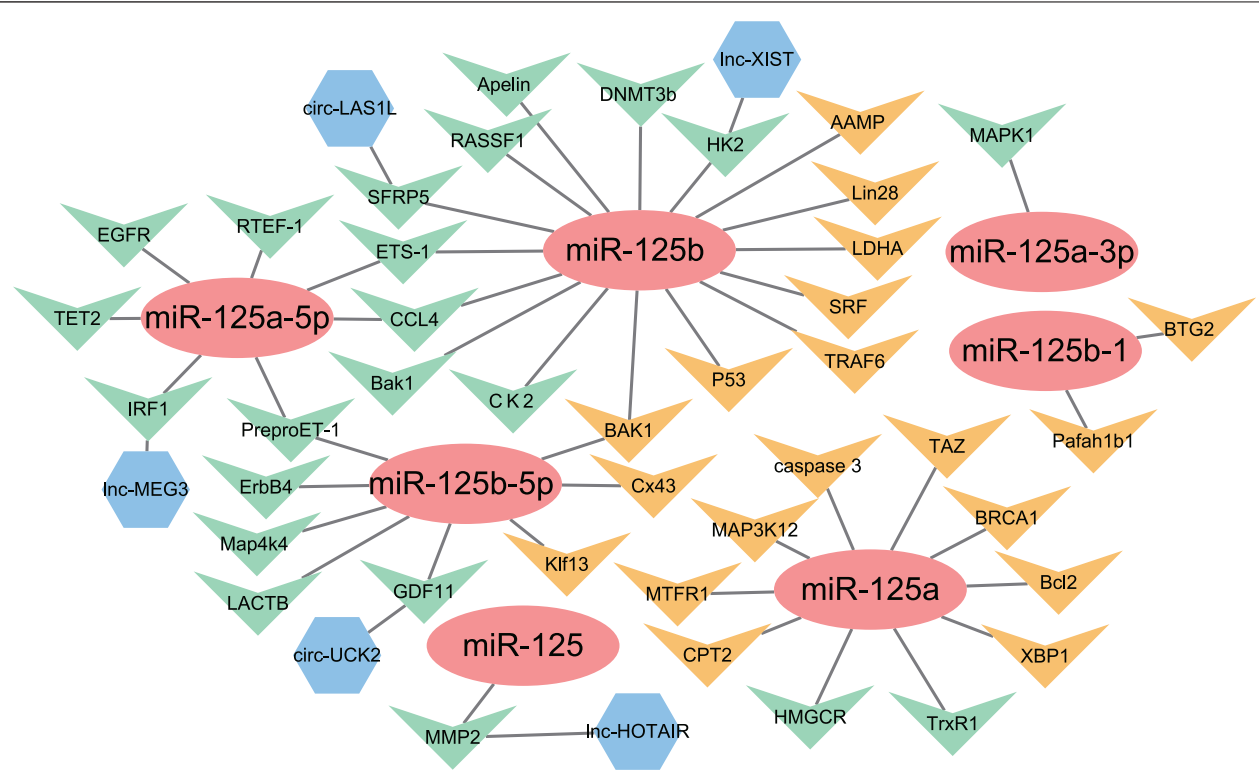

FIGURE 2 | The network of miR-125 family members with their upstream genes and downstream genes. $(\longrightarrow)$ miRNA-125 family members; ( ) = Downstream target genes verified by luciferase assay; $(\quad)$ = Downstream target genes without luciferase assay; $(\square)$ = Upstream target genes verified by luciferase assay.

lysates, it could improve the maturity and increase the expression of cardiomyocyte maturation markers in m/hESC-CMs. The reason for this phenomenon was that four miRNAs targeting ErbB4, including miR-125b-5p, overexpressed in m/hESC-CMs during the period when they were co-cultured with endothelial cells (Lee et al., 2015). This was probably because miRNAs from endothelial cells were released in the form of cell vesicles and absorbed by $\mathrm{m} / \mathrm{hESC}-\mathrm{CMs}$ during the co-cultivation process, thus increasing the maturity of $\mathrm{m} / \mathrm{hESC}-\mathrm{CMs}$.

In another study on human ESCs (Wong et al., 2012), researchers found that miR-125b was an important regulator of human ESCs differentiation and development (including myocardium). Overexpression of miR-125b led to early heart disease. The upregulation of transcription factors, GATA4 and Nkx2-5, accelerated the progress of human embryonic stem cellderived myocardial precursors to the phenotype of embryonic cardiomyocytes. In recent years, with the popularization of second-generation sequencing technology, more and more studies have shown that when the body was in a damaged state, large numbers of miRNAs would be released into the circulatory system from the damaged part (Cheng et al., 2019). Therefore, when the myocardium was damaged, the miRNA in the blood could be used as a marker of heart damage to a certain extent (Akat et al., 2014). Dorota Gródecka-Szwajkiewicz et al. analyzed the miRNA profile of umbilical cord blood of the eripheral blood mononuclear cells during the delivery of term infants and preterm infants. Many angiogenesis related miRNAs, including miR-125, decreased significantly in cord blood miRNAs of preterm infants. This may increase the risk of abnormal development and function of the cardiovascular system after these premature infants reached adulthood (Gródecka-Szwajkiewicz et al., 2020).
With the continuous aging, various components in the cell will change, and the cell function will also degrade. The increased expression of miR-125a in arterial endothelial cells of aging mice could regulate angiogenesis by targeting RTEF-1 and regulating the expression of eNOS and VEGF. The low expression of miR$125 \mathrm{a}$ in endothelial cells may be the "youth code" that maintained the normal operation of endothelial cells (Che et al., 2014). In addition, compared with the immune cells of young people, miR$125 \mathrm{~b}$ was lowly expressed in the elderly. The expression of CCL4 was negatively correlated with the expression of miR-125b. CCL4 was an important chemokine of immune cells, which may be one of the reasons why aging had lower immunity compared with young people (Cheng et al., 2015).

\section{MIR-125 FAMILY AND ISCHEMIA-REPERFUSION INJURY}

After analyzing GSE82146 in the GEO database, Hong Ke et al. found that miR-125a and miR-125b may be the key genes that mediate ischemia-reperfusion (I/R) damage (Ke et al., 2019). In another study on $I / R$ injury, more than half of the changes in miRNA expression including miR-125a-3p occurred in the nitrite treatment group compared with the control group $30 \mathrm{~min}$ after myocardial ischemia and $5 \mathrm{~min}$ after reperfusion (HendgenCotta et al., 2017). These studies showed the high sensitivity of miR-125 family to I/R injury, which also provided a favorable reference value for miR-125 family to evaluate the therapeutic effect of $\mathrm{I} / \mathrm{R}$ injury in the future. NF- $\kappa \mathrm{B}$ signal pathway is the key to mediate myocardial injury after $I / R$ injury. Overexpression of $\mathrm{miR}-125 \mathrm{~b}$ in $\mathrm{I} / \mathrm{R}$ injured mice could effectively reduce I/R-induced cardiomyocyte apoptosis, caspase-3/7 and 
caspase- 8 activities, and prevent the activation of NF- $\kappa \mathrm{B}$ pathway after I/R injury (Wang et al., 2014). In the rat I/R injury model, miR-125b could inhibit the expression of CK2 $\alpha$ and regulate the $\mathrm{CK} 2 \alpha / \mathrm{NADPH}$ oxidation signal pathway to protect the rat brain from I/R damage directly (Liang et al., 2018).

In addition to directly targeting downstream mRNA for regulation, ceRNA bonded by miRNA and circRNA influence the expression of mRNA to produce regulation. Cheng Luo et al. found that the expression of circPVT1 in rats with I/R injury increased significantly. It could inhibit the expression of miR$125 \mathrm{~b}$ and miR-200a by targeting them, increase cardiomyocytes apoptosis after I/R injury, and weaken their protective effect on heart muscles (Luo et al., 2021). MiR-125a, together with miR139 and miR-324, could cooperate with urocortin to protect rat myocardium after I/R injury (Díaz et al., 2017). By targeting MAPK1, miR-125a-3p could also inhibited intimal thickening and the function of vascular smooth muscle cells (VSMCs), thereby reducing the degree of restenosis (Hu et al., 2019). In addition, miR-125a could participate in the proliferation of endothelial cells by acting on $\mathrm{Bcl} 2$, caspase- 3 and TrxR1 in vitro experiments (Svensson et al., 2014; Chen et al., 2018). Interventional therapy is the traditional treatment for vascular stenosis. However, I/R injury and restenosis after interventional therapy have always been a major problem for clinicians. All the above studies provide potential targets for the treatment of I/R injury and vascular restenosis after injury from the gene level.

\section{MIR-125 FAMILY AND MYOCARDIAL ISCHEMIA}

Currently, the number of studies of miR-125b is the most among miRNAs related to myocardial ischemia in the miR-125 family. Researchers found that the expression of miR-125b in the plasma of coronary heart disease patients was lower than that of noncoronary heart disease patients. As the Gensini score increased, the level of miR-125b reduced significantly (Ding et al., 2015). Diabetic cardiomyopathies is a special type of heart disease. miR$125 \mathrm{~b}$ and miR-34a could protect cardiomyocytes in high glucose environment. Their action on the HK2 in glucose metabolism and LDHA in lactate metabolism respectively inhibited the glucose metabolism, glucose uptake and lactate metabolism of cardiomyocytes (Xu and Fang, 2021).

Hypercholesterolemia is one of the causes of myocardial ischemia. Ischemic preconditioning could up-regulate the expression of miR-125b-1-3p and activate cardiac selfprotection mechanisms. However, rats with hypercholesterolemia could attenuate the up-regulation of miR-125b-1-3p level through ischemic preconditioning, which was related to the loss of cardioprotection (Szabó et al., 2020). Myocardial infarction (MI) is one of the main types of myocardial ischemia. Accurate and timely diagnosis of acute myocardial infarction (AMI) is particularly important for a good prognosis of patients. After analyzing the plasma miRNA data of AMI patients, it was found that miR-125b-5p and miR-30d-5p could be used to diagnose AMI effectively. Compared with the existing diagnostic methods of $\mathrm{CK}-\mathrm{MB}, \mathrm{cTnI}$ and myoglobin, the diagnostic performance of miRNA could be comparable to or even exceed the potential of existing diagnostic indicators (Jia et al., 2016). All of these contribute a new idea to the diagnosis of myocardial ischemia in our clinical work. Cardiomyocyte apoptosis is a common pathological process after myocardial ischemia. Up-regulation of miR-125b in cardiomyocytes could reduce the protein levels of apoptosis-related markers c-caspase- 3 and Bax significantly, and increase the expression of antiapoptotic protein $\mathrm{Bcl}-2$ to increase the survival rate of cardiomyocytes (Zhang et al., 2021). In addition, miR-125b could also inhibit cardiomyocytes apoptosis by inhibiting the expression of RASSF1 and KLF3 (Bayoumi et al., 2018; Xiaochuan et al., 2020). lncRNA is another non-coding RNA which has the similar function with circRNA. It can form ceRNA with miRNA to weaken the post-transcriptional modification effect of miRNA on mRNA. In H9C2 cells, lncRNA-XIST could form ceRNA with miR-125b to affect the downstream HEK2 gene, which could weaken the cardioprotective effect of miR-125b and result in cardiomyocytes damage (Fan et al., 2020).

Myocardial fibrosis is an important cause of decreased heart function after myocardial ischemia. When heart was injured, the Ang II-TGF- $\beta$ axis could influence the expression of miR-125b, and then inhibit the expression of apelin and p53, leading to the proliferation of fibroblasts and the conversion of fibroblasts to myofibroblasts. The final outcome of the increase in miR-125b level was the occurrence of myocardial remodeling (Nagpal et al., 2016). The effect of miR-125a did seem to be opposite to that of miR-125b. Similarly, in H9C2 cells, miR-125a mimics reduced the expression of MMP2 and the proliferation of it, while promoting its apoptosis. However, lnc-HOTAIR could restore the expression of MMP2 by targeting miR-125a. At the same time, it could also promote the proliferation and survival of $\mathrm{H} 9 \mathrm{C} 2$ (Li et al., 2018). In cardiac fibroblasts from patients with AMI, circ-LAS1L could bind to miR-125b to relieve the inhibitory effect on downstream SFRP5. Furthermore, it could inhibit the activation, proliferation and migration, and promote apoptosis of cardiac fibroblasts (Bie et al., 2016; Sun et al., 2020). Compared with WT mice, the MI model of AMPKal knocked out conditionally showed more severe myocardial remodeling. Interfering with AMPKa1 expression in fibroblasts could also reduce the expression of $\mathrm{Cx} 43$ protein significantly. However, deletion of AMPKa1 could only reduce the activity of $\mathrm{Cx} 43$ promoter by about $40 \%$, which was inconsistent with the expression of $\mathrm{Cx} 43$ protein. By using a preliminary quantitative PCR microRNA array, the authors showed that AMPKa1, in addition to binding directly to $\mathrm{Cx} 43$, could perform post-transcriptional control of $\mathrm{Cx} 43$ by upregulating miR-125b in its own absence (Dufeys et al., 2021).

\section{MIR-125 FAMILY AND ATHEROSCLEROSIS}

As we all know, atherosclerosis (AS) is a chronic and complex disease involving multiple factors, and it is one of the main causes of coronary heart disease, myocardial ischemia, and cerebral infarction. By comparing the miRNA in 
symptomatic with asymptomatic atherosclerotic plaques after surgical resection Pierre Maitrias et al. found that miR-125a was significantly different between the two groups (Maitrias et al., 2015). This implies that miR-125a plays an important role in the changes of atherosclerotic plaques at different stages of the disease. Macrophages are important participants in the AS process. It is of great significance to reduce the aggregation of macrophages and protect damaged endothelial cells from inflammation in the control of AS. MCP-1 is an important chemokine for macrophages. In THP-1 macrophage cell line, miR-125b$5 p$ could inhibit the expression of MCP-1 by targeting LACTB and attenuate the chemotaxis of macrophages ( $\mathrm{Lu}$ et al., 2016). Pyroptosis is a new mode of programmed cell death that has been discovered and confirmed in recent years, and its development is often accompanied the release of massive inflammatory factors. TET2 was an important member of the TET enzyme family and played an important role in epigenetics (Shen et al., 2018). After treating the endothelial cell surface with oxLDL in vitro, the increased expression of miR-125a-5p could reduce the expression of TET2. Inactivation of TET2 could result in abnormal DNA methylation, NF- $\kappa \mathrm{B}$ nuclear transposition, inflammatory response, and subsequent pyroptosis (Zhaolin et al., 2019).

With the development of the disease, VSMCs subjected to inflammatory stimulation will proliferate, migrate, and invade. This is one of the causes of plaque formation, arterial calcification, and stenosis. As we mentioned before, miR-125b had a targeting relationship with CCL4 (Cheng et al., 2015). Interestingly, in VSMCs, miR-125a also had a targeting relationship with CCL4. This combination could inhibit the expression of NLRP3 and alleviate the inflammatory process (Wang et al., 2019b). Ping Wen et al. treated primary rat VSMCs cultured in vitro with $\beta$-glycerophosphate and found that the $\beta$-glycerophosphate promoted the phenotypic transition and calcification of VSMCs. Besides, they found that the expression of miR125b decreased significantly. After the VSMCs transfected with miR-125b mimics, they could resist $\beta$-glycerophosphatemediated cell differentiation and calcification (Wen et al., 2014). The effect on inhibiting the proliferation of VSMCs of miR-125b was also confirmed in previous study. In the cell model of homocysteine-induced VSMCs proliferation, miR$125 \mathrm{~b}$ could counteract the proliferation of VSMCs by targeting DNMT3b and mediating p53 DNA methylation (Cao et al., 2016). In addition, miR-125b could also inhibit the proliferation and migration of VSMCs by inhibiting the expression levels of AAMP and SRF (Wang et al., 2021). The function of miR-125a on VSMCs was the same as miR-125b, and both of them could inhibit the proliferation and migration of VSMCs. miR-125a could play a role by inhibiting EST1, which was related to cell proliferation and migration in the PDGF-BB pathway (Gareri et al., 2017). In addition, miR-125a could also work by targeting IRF1, EGFR and HMGcr in VSMCs (Zheng et al., 2019; Ye et al., 2020; Zhou et al., 2021).

\section{MIR-125 FAMILY AND OTHER CARDIOVASCULAR AND CEREBROVASCULAR DISEASES}

At present, many of the cardiovascular and cerebrovascular patients would develop heart failure gradually as the diseases progress (Sulo et al., 2020). In patients with heart failure, the expression of miR-125b would rise significantly (Ben-Zvi et al., 2020). And in patients with advanced heart failure, there were significant differences in the expression of three miRNAs including miR-125a-5p, which were related to the composite end point of cardiac death, cardiac transplantation, or mechanical circulatory support implantation (Galluzzo et al., 2021). These studies had important predictive reference value for the prognosis of patients with heart failure.

In terms of pathogenesis, there are many similarities between ischemic stroke and myocardial ischemia. For example, in addition to being a marker of myocardial ischemia, the miR125 family could also be used as a potential biomarker for acute vertigo, posterior circulation stroke and acute ischemic stroke (Tiedt et al., 2017; Kijpaisalratana et al., 2020). In a large casecontrol study (210 participants in the control group, 210 participants in the acute ischemic stroke group), the researchers found that the expression of miR-125a decreased in the plasma of the experimental group. The reason for this decline was that lnc-NEAT1 inhibited its expression (Li et al., 2020). The other lnc-ITSN1-2 inhibited the expression of miRNA such as miR-125a via inactivating its anti-angiogenesis and antiinflammatory effects. The ultimate result was changes in alter vascular structure as well as inflammation related NF- $\mathrm{kB}$ pathway and TRL pathway activation (Zhang and Niu, 2020). In addition, the reduction of miR-125a-5p and miR-125b-5p expression was also related to the expression of preproET-1 in the aorta of strokesusceptible spontaneous hypertensive rats (SHR-SPs) (Li et al., 2010). This provided new and strong evidence for the miR-125 family to participate in the maintenance of vascular homeostasis in the body. In the process of ischemic stroke, circ-UCK2 could act as an endogenous miR-125b-5p sponge to inhibit the activity of miR-125b-5p, which in turn led to an increase in GDF11 expression and improved neuronal damage subsequently (Chen et al., 2020).

\section{MIR-125 AND MESENCHYMAL STEM CELLS AND THEIR EXTRACELLULAR VESICLES}

The current treatments for cardiovascular and cerebrovascular diseases, such as interventions and drugs, have certain therapeutic effects. However, in many cases, conventional treatments cannot save the dying tissues. Mesenchymal stem cells (MSCs) are a kind of stem cells with multiple differentiation potentials and a promising treatment for cardiovascular and cerebrovascular diseases. By far, stem cell therapy has been partially applied to the clinical work of cardiovascular and cerebrovascular diseases (Hu et al., 2011). miR-125b-5p was highly expressed in the miRNA profiles of extracellular vesicles isolated from MSCs 
derived from cord blood and adipose tissues (Nazari-Shafti et al., 2020). This is the basis of MSCs and their vesicles in the treatment of cardiovascular and cerebrovascular diseases.

In the ApoE-/- mice model of AS, the researchers found that the exosomal miR-125b-5p from mouse bone marrow mesenchymal stem cells (BMSCs) inhibited the formation of atherosclerotic plaques by inhibiting the expression of Map4k4 (Lin et al., 2021). P53 was an important apoptosis-regulating gene in organisms, and it could regulate the apoptosis process of cells in a variety of ways (Hafner et al., 2019). Studies have found that transplantation of MSCs or their exosomes could effectively inhibit the autophagy flux, cell death and P53 gene expression of cardiomyocytes after MI. And the therapeutic effect of the MSCs-exosome treatment group is significantly better than that of the MSCs-exosome-antimiR-125b group. Therefore, stem cells and their exosomes were likely to inhibit autophagy flux and target P53 through miR-125b, thereby inhibiting the apoptosis process of cardiomyocytes mediated by $\mathrm{P} 53$ gene and protecting cardiomyocytes (Xiao et al., 2018). It has been reported that when they were used to treat ischemic mouse body models, MSCs could improve their ability to promote functional angiogenesis after undergoing a hypoxia process (Huang et al., 2013). So, if the MSCs are pretreated with hypoxia, will their ability to treat cardiovascular and cerebrovascular diseases be improved? The answer is yes. MI mice treated with exosomes of BMMCs after $72 \mathrm{~h}$ of hypoxia culture had a significant reduction in the area of MI. Next-generation sequencing showed that hypoxia treatment could significantly increase the content of miR-125b-5p in exosomes of BMMCs, and this mechanism of action was due to the ability of miR-125b to inhibit the expression of proapoptotic genes P53 and BAK1 in cardiomyocytes (Zhu et al., 2018). This study proved the highly effective treatment effect of miR-125 family members on MI again.

\section{CONCLUSION}

More and more studies have shown that miR-125 family is related to the development and differentiation of mammalian embryonic heart. Furthermore, they were found played an important role in diseases and pathophysiological processes such as, coronary heart disease, MI, I/R injury, stroke, myocardial fibrosis, endothelial cell injury and myocardial cell apoptosis. However, in different

\section{REFERENCES}

Akat, K. M., Moore-McGriff, D., Morozov, P., Brown, M., Gogakos, T., Correa Da Rosa, J., et al. (2014). Comparative RNA-Sequencing Analysis of Myocardial and Circulating Small RNAs in Human Heart Failure and Their Utility as Biomarkers. Proc. Natl. Acad. Sci. 111 (30), 11151-11156. doi:10.1073/ pnas.1401724111

Bayoumi, A. S., Park, K.-m., Wang, Y., Teoh, J.-p., Aonuma, T., Tang, Y., et al. (2018). A Carvedilol-Responsive microRNA, miR-125b-5p Protects the Heart from Acute Myocardial Infarction by Repressing Pro-apoptotic Bakl and Klf13 in Cardiomyocytes. J. Mol. Cell. Cardiol. 114, 72-82. doi:10.1016/j.yjmcc.2017.11.003

Ben-Zvi, I., Volinsky, N., Grosman-Rimon, L., Haviv, I., Rozen, G., Andria, N., et al. (2020). Cardiac-peripheral Transvenous Gradients of microRNA Expression in diseases and different pathological processes, the same miR125 family members play different roles. That is very interesting. For example, overexpression of miR-125b in cardiomyocytes can inhibit cardiomyocyte apoptosis and inflammatory response in pathological state to protect cardiomyocytes. But at the same time, miR-125b is also a regulator of cardiac fibrosis. Its overexpression in cardiac fibroblasts can enhance their proliferation and reduce their apoptosis. Therefore, excessive miR-125b will aggravate myocardial fibrosis and myocardial remodeling under pathological conditions, destroy the original morphological structure of the heart, increase the difficulty of neovascularization, and aggravate the apoptosis of cardiomyocytes in the damaged area.

As mentioned above, if miR-125 is used as a treatment target of cardiovascular and cerebrovascular diseases in clinical practice, further studies have to take the following two points into account. Firstly, because some miR-125 family members have 'two sides' in the role of cardiovascular and cerebrovascular diseases, we should find the best 'balance point' between harmful and beneficial to give full play to its maximum treatment and circumvent its negative effects. Secondly, in the future, it may not be enough to only study the optimal therapeutic dose of miR-125 in the process of diagnosis and treatment. It is also necessarily need to find a suitable miR-125 vector that can target our target cells for "precision treatment". Only in this way can we give full play to the optimal therapeutic effect of miR-125 family members.

\section{AUTHOR CONTRIBUTIONS}

YW, CF and QW designed and wrote the manuscript. LW, GP, $\mathrm{HC}, \mathrm{QZ}, \mathrm{SW}$ and $\mathrm{CH}$ revised the manuscript. JT drew the figures. CF and QW provided critical feedback and helped to shape the manuscript. All authors listed have made a substantial contribution to the work.

\section{FUNDING}

The study was funded by National Key R\&D Program of China (Grand No. 2020YFC2008502) and 1.3.5 Project for Disciplines of Excellence, West China Hospital, Sichuan University

Systolic Heart Failure Patients. ESC Heart Fail. 7 (3), 835-843. doi:10.1002/ ehf2.12597

Bie, Z.-d., Sun, L.-y., Geng, C.-l., Meng, Q.-g., Lin, X.-j., Wang, Y.-f., et al. (2016). MiR-125b Regulates SFRP5 Expression to Promote Growth and Activation of Cardiac Fibroblasts. Cell Biol Int 40 (11), 1224-1234. doi:10.1002/cbin.10677

Cao, C., Zhang, H., Zhao, L., Zhou, L., Zhang, M., Xu, H., et al. (2016). miR-125b Targets DNMT3b and Mediates P53 DNA Methylation Involving in the Vascular Smooth Muscle Cells Proliferation Induced by Homocysteine. Exp. Cel Res. 347 (1), 95-104. doi:10.1016/j.yexcr.2016.07.007

Che, P., Liu, J., Shan, Z., Wu, R., Yao, C., Cui, J., et al. (2014). miR-125a-5p Impairs Endothelial Cell Angiogenesis in Aging Mice via RTEF -1 Downregulation. Aging cell 13 (5), 926-934. doi:10.1111/acel.12252

Chen, C.-Y., Lee, D. S., Choong, O. K., Chang, S.-K., Hsu, T., Nicholson, M. W., et al. (2021). Cardiac-specific microRNA-125b Deficiency Induces Perinatal 
Death and Cardiac Hypertrophy. Sci. Rep. 11 (1), 2377. doi:10.1038/s41598021-81700-y

Chen, F., Liu, H., Wu, J., and Zhao, Y. (2018). miR-125a Suppresses TrxR1 Expression and Is Involved in $\mathrm{H} 2 \mathrm{O} 2$-Induced Oxidative Stress in Endothelial Cells. J. Immunol. Res. 2018, 1-7. doi:10.1155/2018/6140320

Chen, W., Wang, H., Feng, J., and Chen, L. (2020). Overexpression of circRNA circUCK2 Attenuates Cell Apoptosis in Cerebral Ischemia-Reperfusion Injury via miR-125b-5p/GDF11 Signaling. Mol. Ther. - Nucleic Acids 22, 673-683. doi:10.1016/j.omtn.2020.09.032

Cheng, M., Yang, J., Zhao, X., Zhang, E., Zeng, Q., Yu, Y., et al. (2019). Circulating Myocardial microRNAs from Infarcted Hearts Are Carried in Exosomes and Mobilise Bone Marrow Progenitor Cells. Nat. Commun. 10 (1), 959. doi:10.1038/s41467-019-08895-7

Cheng, N. L., Chen, X., Kim, J., Shi, A. H., Nguyen, C., Wersto, R., et al. (2015). MicroRNA-125b Modulates Inflammatory Chemokine CCL4 Expression in Immune Cells and its Reduction Causes CCL4 Increase with Age. Aging cell 14 (2), 200-208. doi:10.1111/acel.12294

Deng, S., Zhang, Y., Xu, C., and Ma, D. (2015). MicroRNA-125b-2 Overexpression Represses Ectodermal Differentiation of Mouse Embryonic Stem Cells. Int. J. Mol. Med. 36 (2), 355-362. doi:10.3892/ijmm.2015.2238

Díaz, I., Calderón-Sánchez, E., Toro, R. D., Ávila-Médina, J., de Rojas-de Pedro, E. S., Domínguez-Rodríguez, A., et al. (2017). miR-125a, miR-139 and miR-324 Contribute to Urocortin protection against Myocardial Ischemia-Reperfusion Injury. Sci. Rep. 7 (1), 8898. doi:10.1038/s41598-017-09198-x

Ding, X.-Q., Ge, P.-C., Liu, Z., Jia, H., Chen, X., An, F.-H., et al. (2015). Interaction between microRNA Expression and Classical Risk Factors in the Risk of Coronary Heart Disease. Sci. Rep. 5, 14925. doi:10.1038/srep14925

Dufeys, C., Daskalopoulos, E.-P., Castanares-Zapatero, D., Conway, S. J., Ginion, A., Bouzin, C., et al. (2021). AMPKal Deletion in Myofibroblasts Exacerbates post-myocardial Infarction Fibrosis by a Connexin 43 Mechanism. Basic Res. Cardiol. 116 (1), 10. doi:10.1007/s00395-021-00846-y

Fan, J.-L., Zhu, T.-T., Xue, Z.-Y., Ren, W.-Q., Guo, J.-Q., Zhao, H.-Y., et al. (2020). IncRNA-XIST Protects the Hypoxia-Induced Cardiomyocyte Injury through Regulating the miR-125b-Hexokianse 2 axis. In Vitro Cell.Dev.Biol.-Animal 56 (4), 349-357. doi:10.1007/s11626-020-00459-0

Galluzzo, A., Gallo, S., Pardini, B., Birolo, G., Fariselli, P., Boretto, P., et al. (2021). Identification of Novel Circulating microRNAs in Advanced Heart Failure by Next-generation Sequencing. ESC Heart Fail. 8 (4), 2907-2919. doi:10.1002/ehf2.13371

Gao, F., Kataoka, M., Liu, N., Liang, T., Huang, Z.-P., Gu, F., et al. (2019). Therapeutic Role of miR-19a/19b in Cardiac Regeneration and protection from Myocardial Infarction. Nat. Commun. 10 (1), 1802. doi:10.1038/ s41467-019-09530-1

Gareri, C., Iaconetti, C., Sorrentino, S., Covello, C., De Rosa, S., and Indolfi, C. (2017). miR-125a-5p Modulates Phenotypic Switch of Vascular Smooth Muscle Cells by Targeting ETS-1. J. Mol. Biol. 429 (12), 1817-1828. doi:10.1016/j.jmb.2017.05.008

Gródecka-Szwajkiewicz, D., Ulańczyk, Z., Zagrodnik, E., Łuczkowska, K., Rogińska, D., Kawa, M. P., et al. (2020). Differential Secretion of Angiopoietic Factors and Expression of MicroRNA in Umbilical Cord Blood from Healthy Appropriate-For-Gestational-Age Preterm and Term Newborns-In Search of Biomarkers of Angiogenesis-Related Processes in Preterm Birth. Ijms 21 (4), 1305. doi:10.3390/ijms21041305

Hafner, A., Bulyk, M. L., Jambhekar, A., and Lahav, G. (2019). The Multiple Mechanisms that Regulate P53 Activity and Cell Fate. Nat. Rev. Mol. Cel Biol 20 (4), 199-210. doi:10.1038/s41580-019-0110-x

Hendgen-Cotta, U. B., Messiha, D., Esfeld, S., Deenen, R., Rassaf, T., and Totzeck, M. (2017). Inorganic Nitrite Modulates miRNA Signatures in Acute Myocardial In Vivo Ischemia/reperfusion. Free Radic. Res. 51 (1), 91-102. doi:10.1080/10715762.2017.1282158

Hu, S., Liu, S., Zheng, Z., Yuan, X., Li, L., Lu, M., et al. (2011). Isolated Coronary Artery Bypass Graft Combined with Bone Marrow Mononuclear Cells Delivered through a Graft Vessel for Patients with Previous Myocardial Infarction and Chronic Heart Failure. J. Am. Coll. Cardiol. 57 (24), 2409-2415. doi:10.1016/j.jacc.2011.01.037

Hu, W., Chang, G., Zhang, M., Li, Y., Yin, L., Huang, Y., et al. (2019). MicroRNA-125a-3p Affects Smooth Muscle Cell Function in Vascular Stenosis. J. Mol. Cell. Cardiol. 136, 85-94. doi:10.1016/j.yjmcc.2019.08.014
Huang, C.-C., Chen, D.-Y., Wei, H.-J., Lin, K.-J., Wu, C.-T., Lee, T.-Y., et al. (2013). Hypoxia-induced Therapeutic Neovascularization in a Mouse Model of an Ischemic Limb Using Cell Aggregates Composed of HUVECs and cbMSCs. Biomaterials 34 (37), 9441-9450. doi:10.1016/j.biomaterials.2013.09.010

Jia, K., Shi, P., Han, X., Chen, T., Tang, H., and Wang, J. (2016). Diagnostic Value of miR-30d-5p and miR-125b-5p in Acute Myocardial Infarction. Mol. Med. Rep. 14 (1), 184-194. doi:10.3892/mmr.2016.5246

Ke, H., Zhang, X., Cheng, L., Fan, Y., Xiao, S., Ma, Y., et al. (2019). Bioinformatic Analysis to Explore Key Genes Associated with Brain Ischemia-Reperfusion Injury in Rats. Int. J. Neurosci. 129 (10), 945-954. doi:10.1080/ 00207454.2019 .1595615

Kijpaisalratana, N., Nimsamer, P., Khamwut, A., Payungporn, S., Pisitkun, T., Chutinet, A., et al. (2020). Serum miRNA125a-5p, miR-125b-5p, and miR433-5p as Biomarkers to Differentiate between Posterior Circulation Stroke and Peripheral Vertigo. BMC Neurol. 20 (1), 372. doi:10.1186/s12883-02001946-3

Kim, K.-H., Seo, Y.-M., Kim, E.-Y., Lee, S.-Y., Kwon, J., Ko, J.-J., et al. (2016). The miR-125 Family Is an Important Regulator of the Expression and Maintenance of Maternal Effect Genes during Preimplantational Embryo Development. Open Biol. 6 (11), 160181. doi:10.1098/rsob.160181

Lagos-Quintana, M., Rauhut, R., Yalcin, A., Meyer, J., Lendeckel, W., and Tuschl, T. (2002). Identification of Tissue-specific MicroRNAs from Mouse. Curr. Biol. 12, 735-739. doi:10.1016/s0960-9822(02)00809-6

Lee, D. S., Chen, J.-H., Lundy, D. J., Liu, C.-H., Hwang, S.-M., Pabon, L., et al. (2015). Defined MicroRNAs Induce Aspects of Maturation in Mouse and Human Embryonic-Stem-Cell-Derived Cardiomyocytes. Cel Rep. 12 (12), 1960-1967. doi:10.1016/j.celrep.2015.08.042

Li, D., Yang, P., Xiong, Q., Song, X., Yang, X., Liu, L., et al. (2010). MicroRNA125a/b-5p Inhibits Endothelin-1 Expression in Vascular Endothelial Cells. J. Hypertens. 28 (8), 1646-1654. doi:10.1097/HJH.0b013e32833a4922

Li, L., Zhang, M., Chen, W., Wang, R., Ye, Z., Wang, Y., et al. (2018). LncRNAHOTAIR Inhibition Aggravates Oxidative Stress-Induced H9c2 Cells Injury through Suppression of MMP2 by miR-125. Acta Biochim. Biophys. Sinica 50 (10), 996-1006. doi:10.1093/abbs/gmy102

Li, P., Duan, S., and Fu, A. (2020). Long Noncoding RNA NEAT1 Correlates with Higher Disease Risk, Worse Disease Condition, Decreased miR-124 and miR125a and Predicts Poor Recurrence-free Survival of Acute Ischemic Stroke. J. Clin. Lab. Anal. 34 (2), e23056. doi:10.1002/jcla.23056

Liang, Y., Xu, J., Wang, Y., Tang, J.-Y., Yang, S.-L., Xiang, H.-G., et al. (2018). Inhibition of MiRNA-125b Decreases Cerebral Ischemia/Reperfusion Injury by Targeting CK2 $\alpha /$ NADPH Oxidase Signaling. Cell Physiol Biochem 45 (5), 1818-1826. doi:10.1159/000487873

Liao, Y., Li, H., Cao, H., Dong, Y., Gao, L., Liu, Z., et al. (2021). Therapeutic Silencing miR-146b-5p Improves Cardiac Remodeling in a Porcine Model of Myocardial Infarction by Modulating the Wound Reparative Phenotype. Protein Cell 12 (3), 194-212. doi:10.1007/s13238-020-00750-6

Lin, F., Zhang, S., Liu, X., and Wu, M. (2021). Mouse Bone Marrow Derived Mesenchymal Stem Cells-Secreted Exosomal microRNA-125b-5p Suppresses Atherosclerotic Plaque Formation via Inhibiting Map4k4. Life Sci. 274, 119249. doi:10.1016/j.lfs.2021.119249

Lu, J.-B., Yao, X.-X., Xiu, J.-C., and Hu, Y.-W. (2016). MicroRNA-125b-5p Attenuates Lipopolysaccharide-Induced Monocyte Chemoattractant Protein-1 Production by Targeting Inhibiting LACTB in THP-1 Macrophages. Arch. Biochem. Biophys. 590, 64-71. doi:10.1016/j.abb.2015.11.007

Ludwig, N., Leidinger, P., Becker, K., Backes, C., Fehlmann, T., Pallasch, C., et al. (2016). Distribution of miRNA Expression across Human Tissues. Nucleic Acids Res. 44 (8), 3865-3877. doi:10.1093/nar/gkw116

Luo, C., Ling, G.-x., Lei, B.-f., Feng, X., Xie, X.-y., Fang, C., et al. (2021). Circular RNA PVT1 Silencing Prevents Ischemia-Reperfusion Injury in Rat by Targeting microRNA-125b and microRNA-200a. J. Mol. Cell. Cardiol. 159, 80-90. doi:10.1016/j.yjmcc.2021.05.019

Maitrias, P., Metzinger-Le Meuth, V., Massy, Z. A., M’Baya-Moutoula, E., Reix, T., Caus, T., et al. (2015). MicroRNA Deregulation in Symptomatic Carotid Plaque. J. Vasc. Surg. 62 (5), 1245-1250. doi:10.1016/j.jvs.2015.06.136

Nagpal, V., Rai, R., Place, A. T., Murphy, S. B., Verma, S. K., Ghosh, A. K., et al. (2016). MiR-125b Is Critical for Fibroblast-To-Myofibroblast Transition and Cardiac $\begin{array}{llll}\text { Fibrosis. Circulation } 133 & \text { (3), 291-301. doi:10.1161/ }\end{array}$ CIRCULATIONAHA.115.018174 
Nazari-Shafti, T. Z., Neuber, S., Duran, A. G., Exarchos, V., Beez, C. M., Meyborg, H., et al. (2020). MiRNA Profiles of Extracellular Vesicles Secreted by Mesenchymal Stromal Cells-Can They Predict Potential Off-Target Effects. Biomolecules 10 (9), 1353. doi:10.3390/biom10091353

Perge, P., Nagy, Z., Decmann, Á., Igaz, I., and Igaz, P. (2017). Potential Relevance of microRNAs in Inter-species Epigenetic Communication, and Implications for Disease Pathogenesis. RNA Biol. 14 (4), 391-401. doi:10.1080/ 15476286.2016.1251001

Qiao, L., Hu, S., Liu, S., Zhang, H., Ma, H., Huang, K., et al. (2019). microRNA-215p Dysregulation in Exosomes Derived from Heart Failure Patients Impairs Regenerative Potential. J. Clin. Invest. 129 (6), 2237-2250. doi:10.1172/ jci123135

Rodriguez, A., Ashurst, J. L., and Bradley, A. (2004). Identification of Mammalian microRNA Host Genes and Transcription Units. Genome Res. 14, 1902-1910. doi:10.1101/gr.2722704

Roth, G. A., Mensah, G. A., Johnson, C. O., Addolorato, G., Ammirati, E., Baddour, L. M., et al. (2020). Global Burden of Cardiovascular Diseases and Risk Factors, 19902019: Update from the GBD 2019 Study. J. Am. Coll. Cardiol. 76 (25), 2982-3021. doi:10.1016/j.jacc.2020.11.010

Shen, Q., Zhang, Q., Shi, Y., Shi, Q., Jiang, Y., Gu, Y., et al. (2018). Tet2 Promotes Pathogen Infection-Induced Myelopoiesis through mRNA Oxidation. Nature 554 (7690), 123-127. doi:10.1038/nature25434

Sulo, G., Sulo, E., Jørgensen, T., Linnenberg, A., Prescott, E., Tell, G. S., et al. (2020). Ischemic Heart Failure as a Complication of Incident Acute Myocardial Infarction: Timing and Time Trends: A National Analysis Including 78,814 Danish Patients during 2000-2009. Scand. J. Public Health 48 (3), 294-302. doi:10.1177/ 1403494819829333

Sun, L. y., Zhao, J. c., Ge, X. m., Zhang, H., Wang, C. m., and Bie, Z. d. (2020). Circ_LAS1L Regulates Cardiac Fibroblast Activation, Growth, and Migration through miR-125b/SFRP5 Pathway. Cell Biochem Funct 38 (4), 443-450. doi:10.1002/cbf.3486

Sun, Y.-M., Lin, K.-Y., and Chen, Y.-Q. (2013). Diverse Functions of miR-125 Family in Different Cell Contexts. J. Hematol. Oncol. 6, 6. doi:10.1186/1756-8722-6-6

Svensson, D., Gidlöf, O., Turczyńska, K. M., Erlinge, D., Albinsson, S., and Nilsson, B.-O. (2014). Inhibition of microRNA-125a Promotes Human Endothelial Cell Proliferation and Viability through an Antiapoptotic Mechanism. J. Vasc. Res. 51 (3), 239-245. doi:10.1159/000365551

Szabó, M. R., Gáspár, R., Pipicz, M., Zsindely, N., Diószegi, P., Sárközy, M., et al. (2020). Hypercholesterolemia Interferes with Induction of miR-125b$1-3 p$ in Preconditioned Hearts. Ijms 21 (11), 3744. doi:10.3390/ ijms 21113744

Tiedt, S., Prestel, M., Malik, R., Schieferdecker, N., Duering, M., Kautzky, V., et al. (2017). RNA-seq Identifies Circulating miR-125a-5p, miR-125b-5p, and miR-143-3p as Potential Biomarkers for Acute Ischemic Stroke. Circ. Res. 121 (8), 970-980. doi:10.1161/CIRCRESAHA.117.311572

Wang, J. K., Wang, Z., and Li, G. (2019). MicroRNA-125 in Immunity and Cancer. Cancer Lett. 454, 134-145. doi:10.1016/j.canlet.2019.04.015

Wang, J., Wu, Q., Yu, J., Cao, X., and Xu, Z. (2019). miR-125a-5p I-nhibits the E-xpression of NLRP3 by T-argeting CCL4 in H-uman V-ascular S-mooth M-uscle C-ells T-reated with ox-LDL. Exp. Ther. Med. 18 (3), 1645-1652. doi:10.3892/etm.2019.7717

Wang, X., Chen, S., Gao, Y., Yu, C., Nie, Z., Lu, R., et al. (2021). MicroRNA-125b I-nhibits the P-roliferation of V-ascular S-mooth M-uscle C-ells I-nduced by P-latelet-derived G-rowth F-actor BB. Exp. Ther. Med. 22 (2), 791. doi:10.3892/etm.2021.10223

Wang, X., Ha, T., Zou, J., Ren, D., Liu, L., Zhang, X., et al. (2014). MicroRNA-125b Protects against Myocardial Ischaemia/reperfusion Injury via Targeting P53-Mediated Apoptotic Signalling and TRAF6. Cardiovasc. Res. 102 (3), 385-395. doi:10.1093/ cur/cru044

Wen, P., Cao, H., Fang, L., Ye, H., Zhou, Y., Jiang, L., et al. (2014). miR-125b/Ets1 axis Regulates Transdifferentiation and Calcification of Vascular Smooth Muscle Cells in a
High-Phosphate Environment. Exp. Cel Res. 322 (2), 302-312. doi:10.1016/ j.yexcr.2014.01.025

Wong, S. S. Y., Ritner, C., Ramachandran, S., Aurigui, J., Pitt, C., Chandra, P., et al. (2012). miR-125b Promotes Early Germ Layer Specification through Lin28/let-7d and Preferential Differentiation of Mesoderm in Human Embryonic Stem Cells. PloS one 7 (4), e36121. doi:10.1371/journal.pone.0036121

Xiao, C., Wang, K., Xu, Y., Hu, H., Zhang, N., Wang, Y., et al. (2018). Transplanted Mesenchymal Stem Cells Reduce Autophagic Flux in Infarcted Hearts via the Exosomal Transfer of miR-125b. Circ. Res. 123 (5), 564-578. doi:10.1161/ CIRCRESAHA.118.312758

Xiaochuan, B., Qianfeng, J., Min, X., and Xiao, L. (2020). RASSF1 Promotes Cardiomyocyte Apoptosis after Acute Myocardial Infarction and Is Regulated by miR-125b. J. Cel Biochem 121 (1), 489-496. doi:10.1002/jcb.29236

Xu, C.-r., and Fang, Q.-j. (2021). A Inibição Do Metabolismo da Glicose por miR-34a e miR-125b Protege contra a Morte Celular de Cardiomiócitos Causada por Hiperglicemia. Arquivos brasileiros de cardiologia 116 (3), 415-422. doi:10.36660/ abc.20190529

Ye, D., Lou, G. H., Li, A. C., Dong, F. Q., Chen, G. P., Xu, W. W., et al. (2020). MicroRNA125a-mediated R-egulation of the $\mathrm{M}$-evalonate $\mathrm{S}$-ignaling $\mathrm{P}$-athway $\mathrm{C}$-ontributes to H-igh G-lucose-induced P-roliferation and M-igration of V-ascular S-mooth M-uscle C-ells. Mol. Med. Rep. 22 (1), 165-174. doi:10.3892/mmr.2020.11077

Zhang, B., Mao, S., Liu, X., Li, S., Zhou, H., Gu, Y., et al. (2021). MiR-125b Inhibits Cardiomyocyte Apoptosis by Targeting BAK1 in Heart Failure. Mol. Med. 27 (1), 72. doi:10.1186/s10020-021-00328-w

Zhang, Y., and Niu, C. (2020). The Correlation of Long Non-coding RNA Intersectin 1-2 with Disease Risk, Disease Severity, Inflammation, and Prognosis of Acute Ischemic Stroke. J. Clin. Lab. Anal. 34 (2), e23053. doi:10.1002/jcla.23053

Zhaolin, Z., Jiaojiao, C., Peng, W., Yami, L., Tingting, Z., Jun, T., et al. (2019). OxLDL Induces Vascular Endothelial Cell Pyroptosis through miR-125a-5p/TET2 Pathway. J. Cel Physiol 234 (5), 7475-7491. doi:10.1002/jcp.27509

Zheng, X., Wu, Z., Xu, K., Qiu, Y., Su, X., Zhang, Z., et al. (2019). Interfering Histone Deacetylase 4 Inhibits the Proliferation of Vascular Smooth Muscle Cells via Regulating MEG3/miR-125a-5p/IRF1. Cell Adhes. Migration 13 (1), 41-49. doi:10.1080/ 19336918.2018.1506653

Zhou, H., Lin, S., Hu, Y., Guo, D., Wang, Y., and Li, X. (2021). miR-125a-5p and miR-7 I-nhibits the P-roliferation, M-igration and I-nvasion of V-ascular S-mooth M-uscle C-ell by T-argeting EGFR. Mol. Med. Rep. 24 (4). doi:10.3892/mmr.2021.12347

Zhu, L.-P., Tian, T., Wang, J.-Y., He, J.-N., Chen, T., Pan, M., et al. (2018). Hypoxia-elicited Mesenchymal Stem Cell-Derived Exosomes Facilitates Cardiac Repair through miR125b-Mediated Prevention of Cell Death in Myocardial Infarction. Theranostics 8 (22), 6163-6177. doi:10.7150/thno.28021

Conflict of Interest: The authors declare that the research was conducted in the absence of any commercial or financial relationships that could be construed as a potential conflict of interest.

Publisher's Note: All claims expressed in this article are solely those of the authors and do not necessarily represent those of their affiliated organizations, or those of the publisher, the editors and the reviewers. Any product that may be evaluated in this article, or claim that may be made by its manufacturer, is not guaranteed or endorsed by the publisher.

Copyright (c) 2021 Wang, Tan, Wang, Pei, Cheng, Zhang, Wang, He, Fu and Wei. This is an open-access article distributed under the terms of the Creative Commons Attribution License (CC BY). The use, distribution or reproduction in other forums is permitted, provided the original author(s) and the copyright owner(s) are credited and that the original publication in this journal is cited, in accordance with accepted academic practice. No use, distribution or reproduction is permitted which does not comply with these terms. 